\title{
Principal component analysis of pre-weaning growth traits in Santa Inês lambs ${ }^{1}$
}

\section{Análise de componentes principais para características de crescimento pré-desmame em ovinos da raça Santa Inês}

\author{
Natália Albieri Koritiaki²; Edson Luis de Azambuja Ribeiro ${ }^{3}$; Carolina Amália \\ Souza Dantas Muniz ${ }^{3 *}$; Bruna Silva Marestone ${ }^{4}$; Francisco Fernandes Junior ${ }^{5}$
}

\begin{abstract}
The aim of this study was to evaluate the interrelation among growth traits in Santa Inês lambs using principal component analysis. Data on 270 lambs born between 2008 and 2013 were used. The variables studied were weight at birth, adjusted weights, and average daily gains at 14, 28, 52, and 70 days of age. The wither height, thoracic perimeter, and body length at birth and adjusted at 28 and 70 days of age (weaning), were also used. The statistical model comprised the fixed effects of the contemporary group, the linear effect of julian date at birth, and the linear and quadratic effects of lambing weight. The first principal component explained approximately $89 \%$ and $85 \%$ of the total variation for body weight at different ages and average daily gains, respectively. The second principal component compared heavier animals or those that gained more weight at 14 days with lighter lambs or those that gained less weight at 14 in the other ages explaining $5 \%$ and $10 \%$ of the variation, among the animals. The first principal component accounted for $77 \%, 91 \%$, and $77 \%$ of the variation for weight, thoracic perimeter, wither height, and length at birth, 28 days, and 70 days of age, respectively, and compared large animals or animals with greater body volume. The second component, with values of $16 \%, 6 \%$, and $14 \%$ of the total variation at the three ages, respectively, compared animals with distinct conformation to discriminate animals of different shapes and verified that the weights at the different ages and the thoracic perimeter are important sources of variability among the animals.
\end{abstract}

Keywords: Biometric measures. Multivariate analysis. Selection. Weights.

\section{Resumo}

Objetivou-se com este trabalho avaliar as inter-relações entre as medidas de crescimento em cordeiros da raça Santa Inês no período pré-desmame, utilizando-se a técnica dos componentes principais. Para tanto, contou-se com informações de 270 cordeiros, nascidos entre 2008 e 2013. As variáveis estudadas foram o peso ao nascimento, os pesos corrigidos e ganhos médios diários aos 14, 28, 52 e 70 dias de idade. Foram utilizadas as medidas, altura de cernelha, perímetro torácico e comprimento ao nascimento e corrigidas para os 28 e 70 dias de idade de cordeiros Santa Inês. O modelo estatístico utilizado na análise por componentes principais para todas as características estudadas incluiu os efeitos de grupo de contemporâneos, o efeito linear da data juliana de nascimento e os efeitos linear e quadrático do

1 Parte da Tese de Doutorado da primeira autora.

2 Prof ${ }^{\mathrm{a}} \mathrm{Dr}^{\mathrm{a}}$, Departamento de Estatística, Universidade Estadual de Londrina, UEL, Londrina, PR, Brasil.E-mail: natalia.a.koritiaki@ gmail.com

3 Profs., Drs., Departamento de Zootecnia, UEL, Londrina, PR, Brasil. E-mail: elar@uel.br; muniz@uel.br

4 Discente, Programa de Pós-Graduação em Ciência Animal, UEL, PR, Londrina, PR, Brasil. E-mail: brunamarestone@gmail.com

5 Zootecnista, Londrina, PR, Brasil. E-mail: ffjunior@zootecnista.com.br

* Author for correspondence 
peso da ovelha ao parto. Para os pesos às diferentes idades e os ganhos médios diários o primeiro componente principal acumulou $89 \%$ e $85 \%$ da variação total, respectivamente. O segundo componente contrastou animais mais pesados ou ganharam mais peso aos 14 dias com aqueles que foram mais leves ou ganharam menos pesos nas demais idades, explicando 5 e $10 \%$ da variabilidade entre os animais. Para as medidas de peso, perímetro torácico, altura de cernelha e comprimento ao nascimento, aos 28 dias de idade e aos 70 dias de idade, o primeiro componente, que acumulou $77 \%, 91 \%$ e $77 \%$ da variabilidade existente, respectivamente, comparou animais de maior tamanho ou volume corporal. $\mathrm{O}$ segundo componente, com $16 \%, 6 \%$ e $14 \%$, respectivamente da variabilidade total, comparou animais de diferentes conformações e verificou-se que os pesos nas diferentes idades e o perímetro torácico são importantes fontes de variabilidade entre os animais.

Palavras-chave: Análise multivariada. Medidas biométricas. Pesos. Seleção.

\section{Introduction}

The first step in the implementation of genetic improvement programs is the definition of the selection objectives. It is necessary to identify which traits will be used as selection criteria and the existing relationships between these characteristics.

The techniques of multivariate analysis allow identification of the structure of covariance between various traits, as well as the dependency relations between them. Therefore, they are a complementary tool in genetic improvement. In this sense, the principal component analysis, an exploratory technique, can demonstrate previously unidentified relationships, contributing to a better interpretation of data and consequently, decision making in relation to the characteristics to be selected (BAKER et al., 1988).

The principal component analysis is based on the understanding of the variability resulting from $p$ random variables bound by a multiple dependence relation of $q$ new variables; preferably $q<p$. In this way, the principal components are linear combinations of the original variables, so that they have maximum variance and are orthogonal to each other, with the intention of obtaining the maximum information in terms of the total variance contained in the data. The relative importance of a component is evaluated by the percentage of the total variance it explains (MORRISON, 1976). Principal components can be used to evaluate variations in body shapes and to increase the understanding of structural relationships, rather than individual and independent relationships, making it possible to compare animals of different shapes and sizes (BROWN et al., 1973).

The selection for growth traits during the preweaning stage results in animals with greater potential for growth, which allows the reduction of the duration of the production cycle. In addition, the improvement in the pre-weaning period reflects in better post-weaning performance. Boujane and Diallo (2017) estimated the genetic parameters for pre-weaning traits in Sardi sheep and emphasized the importance of the increase in corporal weight for the increase of meat production. Pires et al. (2015) also estimated genetic parameters for preweaning traits in Suffolk sheep, and pointed out that the search for better quality animals at the preweaning stage is justified by the need to improve sheep production systems in Brazil.

Biometric measures, such as thoracic perimeter, body length, and wither height are important measures of the growth of the animal, in addition to the weights at specific ages. In sheep, these measurements are routinely taken, but it is important to study the interrelationships between these measures during the pre-weaning stage, since they can be used as selection criteria.

Landim et al. (2007) and Guedes et al. (2018) used the principal component technique to verify the relationship between morphometric measurements of carcass in sheep, while Silva et al. (2015) used 
the method to evaluate the relationship between the traits measured after weaning in the performance tests of Morada Nova sheep. Despite these studies, the use of the principal component technique to evaluate growth traits is poorly represented in the literature. The objective of this study was to evaluate the interrelationships between weight traits and the biometric measurements of Santa Inês lambs from birth to weaning using a multivariate technique, the Principal Component Analysis.

\section{Material and Methods}

The data used in this study were obtained from the weight and biometric measurements of 270 lambs of the Santa Inês breed, born in the period from 2008 to 2013 at the School Farm of the Londrina State University, Londrina, Paraná, Brazil, located at $23^{\circ} 23^{\prime} \mathrm{S}$ and $51^{\circ} 11^{\prime} \mathrm{W}$. It is characterized by two distinct climatic seasons, a wet season from October to March, in which rains are abundant and a period of drought, from April to September.

The animals were managed under similar conditions, maintained on Coast-cross pasture (Cynodon dactylon (L.) Pers), with mineral salt available in appropriate troughs, plus a supplement of sorghum silage, and concentrate during the winter periods. Standard sanitary management was followed with control of worm infestation based on the results of faecal egg counts. Weaning occurred at approximately 70 days of age.

Weight and biometric measures were taken weekly from birth to weaning. Three biometric measurements were recorded using a measuring tape: the wither height, measured between the highest point of the interscapular region (wither) and soil; the body length, measured from the wither to the caudal part of the ischial tuberosity; and the thoracic perimeter, measured at the outer circumference of the thoracic cavity near the armpits.

Data file with weight and biometric measures at birth, adjusted at 28 and 70 days of age (weaning), was edited as follows:

$$
X_{a}=\left\{\left[\frac{\left(X_{r}-X_{n}\right)}{A G_{r}}\right] \times A_{a}\right\}+X_{n},
$$

where

$\mathrm{X}_{\mathrm{a}}=$ weight or measure adjusted for the standard age,

$\mathrm{X}_{\mathrm{r}}=$ weight or measure observed at the age considered,

$X_{n}=$ weight or measure observed at birth,

$\mathrm{AG}_{\mathrm{r}}=$ age of the lamb at the time of the measurement, and

$\mathrm{AG}_{\mathrm{a}}=$ standard age.

Body weight and average daily gains from birth to $14,28,42,56$, and 70 days of age were evaluated. Preliminary analyses were conducted with the purpose of identifying the effects that influenced weight and measures of lambs from birth to weaning. Thus, we defined the fixed effect of the contemporary group, which included animals of the same sex, delivered in the same way, in the same year, and at the same season. Groups with less than five animals were excluded. The model used was as follows:

$\mathrm{Y}_{\mathrm{ijk} l}=\mu+\mathrm{CG}_{\mathrm{i}}+\mathrm{b}_{1}\left(\mathrm{PM}_{\mathrm{ij}}\right)+\mathrm{b}_{2}\left(\mathrm{PM}_{\mathrm{ij}}\right)^{2}+\mathrm{b}_{3}\left(\mathrm{DJN}_{\mathrm{ijk}}\right)+\varepsilon_{\mathrm{ijk}}$,

where

$\mathrm{Y}_{\mathrm{ijkl}}=$ dependent variables (weight or body measurement),

$\mu=$ overall average,

$\mathrm{CG}_{\mathrm{i}}=$ effect of the $\mathrm{i}$-th contemporary group $(\mathrm{i}=1$, ..., 27),

$b_{1}$ and $b_{2}=$ coefficients of linear and quadratic regression, respectively,

$\mathrm{PM}_{\mathrm{ij}}=$ fixed effect of the $\mathrm{j}$-th weight of the mother at birth,

$\mathrm{b}_{3}=$ coefficient of linear regression, 
$\mathrm{DJN}_{\mathrm{ijk}}=$ effect of the k-th julian date of birth, and

$\varepsilon_{\mathrm{ijkl}}=$ random error associated with each observation.

Considering the fact that the traits under study have different units of measurement, it was necessary to standardize the variables for the estimation of the principal component. It is recommended that principal component analysis be preceded by standardization, since the data at different scales make the variables with greater variance have a larger weight in the first components than those with smaller variance (MORRISON, 1976).

$$
Z_{i j}=\frac{X_{i j}-\mu_{x j}}{S_{j}},
$$

where

$\mathrm{Z}_{\mathrm{ij}}=$ standardized variable,

$\mathrm{X}_{\mathrm{ij}}=$ original variable,

$\mu_{\mathrm{xj}}=$ average of the original variable, and

$S_{j}=$ standard deviation of the original variable.

The principal components were determined by solving the characteristic equation of the matrix of covariance, using the following expressions (MORRISON, 1976):

$|\mathrm{S}-\lambda \mathrm{I}|=0$, obtaining eigenvalues $\lambda_{1}, \lambda_{2}, \ldots, \lambda_{\mathrm{p}}$ and

$[\mathrm{S}-\lambda \mathrm{I}] \mathrm{a}_{\mathrm{i}}=\varphi$, obtaining eigenvectors $\mathrm{a}_{1}, \mathrm{a}_{2}, \ldots, \mathrm{a}_{\mathrm{p}}$,

where

$\mathrm{S}=$ matrix of covariance among the evaluated traits,

$\lambda_{i}=$ eigenvalues of the matrix $S$,

$a_{i}=$ eigenvector associated with eigenvalue $\lambda_{i}$,

$\mathrm{I}=$ identity matrix of order $\mathrm{p}(\mathrm{p}=$ number of traits $)$,

$\varphi=$ is a null vector, of dimension $\mathrm{p} \times 1$.

The eigenvectors $a_{i}$ were normalized to obtain $\mathrm{a}_{\mathrm{i}}{ }^{*}$ such that $\mathrm{a}_{\mathrm{i}}{ }^{\prime *} \cdot \mathrm{a}_{1}{ }^{*}=1$ for $\mathrm{i}=1,2, \ldots, \mathrm{p}$ and $\mathrm{a}_{\mathrm{i}}{ }^{\prime *} \cdot \mathrm{a}_{1}=0$ for $i \neq j$.
The principal components are linear combinations of the original variables and are estimated so that the first principal components associated with the largest eigenvalues retain the largest percentage of the total variance. Each original variable is associated to the principal component by a weighting coefficient; therefore, the coefficients of greatest absolute value in the components of smaller eigenvalue are less important and can be discarded (MORRISON, 1976).

The principal components were obtained separately for each age with the procedure PRINCOMP in the statistical software SAS (Statistical Analysis System, version 3.5) (2016), using the covariance matrix in which the predicted values were considered. The interpretation of the results was based on the weighting coefficients (eigenvectors) of the pre-weaning growth traits and the percentage of variance (determined by the eigenvalues) for each component such that greater the variance explained by a component, the greater its importance. The eigenvectors are a group of scores of coefficients that correspond to the original variables. Each variable has an eigenvector ranging from 1 to -1 ; values close to 1 and -1 are more important.

\section{Results and Discussion}

The averages and standard deviations of the traits evaluated, as well as the maximum and minimum values, are described in Table 1 . Most of the variance, $89 \%$ and $85 \%$, was explained by the first component of adjusted weight and average daily gains, respectively (Table 2). The relative importance of the principal component is evaluated by the percentage of the total variance explained by the component, so it is verified that the first principal component describes a large part of the variance for weight and weight gain. The importance of the coefficient in the model is indicated by its higher values; in this case, it was more significant (Table 2) for weights adjusted at 28 and 56 days of age and average gains during this same period, which can be used as a criterion to select for superior individuals. 
Table 1. Average, standard deviation, maximum, and minimum values of body weight $(\mathrm{kg})$, average daily gain $(\mathrm{kg}$ day-1), thoracic perimeter $(\mathrm{cm})$, body length $(\mathrm{cm})$, and wither height $(\mathrm{cm})$ of Santa Inês lambs in the pre-weaning period.

\begin{tabular}{lccc}
\hline \multicolumn{1}{c}{ Traits } & Average \pm SD $^{\mathbf{3}}$ & Maximum & Minimum \\
\hline Weight adjusted at birth & $3.87 \pm 0.78$ & 7.04 & 1.95 \\
Weight adjusted at 14 days of age & $6.94 \pm 1.81$ & 13.31 & 2.21 \\
Weight adjusted at 28 days of age & $9.02 \pm 2.60$ & 19.00 & 3.80 \\
Weight adjusted at 42 days of age & $11.25 \pm 3.41$ & 23.23 & 4.16 \\
Weight adjusted at 56 days of age & $13.02 \pm 4.02$ & 26.60 & 4.75 \\
Weight adjusted at 70 days ${ }^{1}$ of age & $13.93 \pm 4.43$ & 26.56 & 5.09 \\
\hline ADG ${ }^{2}$ from birth to 14 days of age & $0.22 \pm 0.11$ & 0.57 & 0.00 \\
ADG from birth to 28 days of age & $0.18 \pm 0.08$ & 0.57 & 0.04 \\
ADG from birth to 42 days of age & $0.18 \pm 0.07$ & 0.39 & 0.02 \\
ADG from birth to 56 days of age & $0.16 \pm 0.06$ & 0.35 & 0.03 \\
ADG from birth to 70 days of age & $0.14 \pm 0.06$ & 0.28 & 0.00 \\
\hline Thoracic perimeter at birth & $37.66 \pm 2.93$ & 48.00 & 27.00 \\
Thoracic perimeter adjusted at 28 days of age & $48.17 \pm 5.13$ & 66.67 & 32.64 \\
Thoracic perimeter adjusted at 70 days of age & $56.90 \pm 6.05$ & 71.55 & 41.81 \\
\hline Length that birth & $27.80 \pm 2.97$ & 36.00 & 20.00 \\
Length adjusted at 28 days of age & $37.24 \pm 4.15$ & 53.00 & 27.23 \\
Length adjusted at 70 days of age & $46.03 \pm 6.81$ & 73.47 & 32.15 \\
\hline Height at birth & $39.61 \pm 2.68$ & 49.00 & 27.00 \\
Wither height adjusted at 28 days of age & $47.90 \pm 3.48$ & 60.13 & 39.88 \\
Wither height adjusted at 70 days of age & $55.38 \pm 4.57$ & 69.00 & 44.86 \\
\hline
\end{tabular}

${ }^{1}$ Weaning; ${ }^{2} \mathrm{ADG}=$ average daily gain; ${ }^{3}$ standard deviation.

Table2. Coefficients of the principal components of adjusted weight and average daily gain of Santa Inês lambs in the pre-weaning period and percentage of variance explained by each component.

\begin{tabular}{lcccccc}
\hline \multirow{2}{*}{\multicolumn{1}{c}{ Traits }} & \multicolumn{7}{c}{ Coefficients of the Principal Components } \\
\cline { 2 - 7 } & PC1 & PC2 & PC3 & PC4 & PC5 & PC6 \\
\hline Weight at birth & 0.39 & -0.26 & 0.84 & 0.21 & 0.16 & 0.04 \\
Weight adjusted at 14 days of age & 0.37 & 0.91 & 0.06 & 0.12 & 0.09 & 0.00 \\
Weight adjusted at 28 days of age & 0.43 & -0.07 & -0.01 & -0.15 & -0.86 & -0.23 \\
Weight adjusted at 42 days of age & 0.42 & -0.10 & -0.15 & -0.54 & 0.13 & 0.69 \\
Weight adjusted at 56 days of age & 0.42 & -0.16 & -0.23 & -0.31 & 0.46 & -0.66 \\
Weight adjusted at 70 days ${ }^{1}$ of age & 0.41 & -0.24 & -0.46 & 0.73 & 0.05 & 0.17 \\
\hline \multicolumn{1}{c}{ Total variance (\%) } & 0.89 & 0.05 & 0.03 & 0.01 & 0.00 & 0.00 \\
\hline \multicolumn{1}{c}{ Traits } & & & & & & \\
\hline ADG ${ }^{2}$ from birth to 14 days of age & 0.45 & -0.25 & 0.84 & 0.06 & 0.18 & -- \\
ADG from birth to 28 days of age & 0.47 & -0.20 & -0.20 & 0.47 & -0.69 & -- \\
ADG from birth to 42 days of age & 0.47 & -0.15 & -0.46 & 0.27 & 0.69 & - \\
ADG from birth to 56 days of age & 0.47 & -0.11 & -0.20 & -0.84 & -0.15 & - \\
ADG from birth to 70 days of age & 0.36 & 0.93 & 0.08 & 0.07 & -0.01 & - \\
\hline \multicolumn{1}{c}{ Total variance (\%) } & 0.85 & 0.10 & 0.02 & 0.01 & 0.00 & -- \\
\hline
\end{tabular}

${ }^{1}$ Weaning; ${ }^{2} \mathrm{ADG}=$ average daily gain. 
The second principal component for adjusted weights and average daily gains accumulated less variability proportions (Table 2) and therefore, presented less importance in relation to the first component. In this case, it compared heavier animals at 14 days with those that were lighter at weaning, and a high coefficient value (0.91) was obtained when the adjusted weight at 14 days of age was high and the weights at the other ages were low. However, if the weight at 14 days was low, this coefficient presented a low value, which makes it important to emphasize the small proportion of variance, $5 \%$, that the second component presents and consequently, its reduced importance. The second principal component for average gains, likewise, compared the highest average daily gains of animals at 70 days of age with those gaining less weight at younger ages.

Muniz et al. (2014), using the technique of principal components in beef cattle for the adjusted weights and average daily gains from weaning to yearling weight, verified that the weight at the oldest age had a higher coefficient, which favored heavier animals for slaughter, and reinforced the idea that older the animal, its weight grows in importance. Muniz et al. (2014) also discussed the comparison of animals with average daily gains determined by birth during different seasons, since the traits were measured from birth to yearling, examining different stages of growth of the animals through different seasons of the year.

In the present study, the coefficients presented the same value for the average daily gain at 28,42 , and 56 days, suggesting that the selection in any of these periods would be possible. However, it should be emphasized that they comprise the same growth period, from birth to weaning and therefore, with no significant distinction between weights and average daily gains during the pre-weaning period.

The first three principal components accounted for $98 \%, 99 \%$, and $96 \%$ of the total variation for the traits weight, thoracic perimeter, wither height, and body length in the three periods: birth, 28 days, and 70 days, respectively (Table 3 ).

Table 3. Coefficients of the principal components of weight, thoracic perimeter, height, and length of Santa Inês lambs in the pre-weaning period and percentage of variance explained by each component.

\begin{tabular}{lcccc}
\hline \multirow{2}{*}{\multicolumn{1}{c}{ Traits }} & \multicolumn{4}{c}{ Coefficients of the Principal Components } \\
\cline { 2 - 5 } & PC1 & PC2 & PC3 & PC4 \\
\hline Weight at birth & 0.54 & -0.02 & -0.53 & -0.65 \\
Thoracic perimeter at birth & 0.54 & -0.19 & -0.35 & 0.74 \\
Wither height at birth & 0.50 & -0.46 & 0.72 & -0.15 \\
Length at birth & 0.40 & 0.86 & 0.30 & 0.07 \\
\hline \multicolumn{1}{c}{ Total variance (\%) $\quad$ Traits } & 0.77 & 0.16 & 0.05 & 0.02 \\
\hline \multicolumn{1}{c}{ Total variance (\%) } & & & \\
\hline Weight adjusted at 28 days of age & 0.52 & 0.03 & -0.44 & -0.73 \\
Thoracic perimeter adjusted at 28 days of age & 0.51 & -0.32 & 0.79 & -0.13 \\
Wither height adjusted at 28 days of age & 0.48 & 0.82 & 0.08 & 0.32 \\
Length adjusted at 28 days of age & 0.50 & -0.48 & -0.42 & 0.58 \\
\hline \multicolumn{1}{c}{$\quad 0.91$} & 0.06 & 0.02 & 0.01 \\
\hline \multicolumn{2}{c}{} & & & continue
\end{tabular}


continuation

\begin{tabular}{|c|c|c|c|c|}
\hline Traits & & & & \\
\hline Weight adjusted at 70 days $^{1}$ of age & 0.52 & 0.18 & -0.77 & -0.33 \\
\hline Thoracic perimeter adjusted at 70 days of age & 0.52 & -0.28 & 0.55 & -0.59 \\
\hline Wither height adjusted at 70 days of age & 0.46 & 0.75 & 0.33 & 0.35 \\
\hline Length adjusted at 70 days of age & 0.49 & -0.58 & -0.07 & 0.65 \\
\hline Total variance $(\%)$ & 0.77 & 0.14 & 0.05 & 0.03 \\
\hline
\end{tabular}

${ }^{1}$ Weaning.

The first major component compared animals with different body sizes or volumes, determined by body weight, thoracic perimeter, body length, and wither height. Similar to the interpretation of the principal components for the adjusted weights and daily average gains presented in Table 2, this first component can serve as a selection index. Animals of greater thoracic perimeter and body weight would be those of larger size or body volume, so this component can be interpreted as a general measure of the size and volume of animals.

Animals above the average for one of these characteristics also exhibit positive deviations in the others. Thus, lambs of greater body weight would also be the largest in size or body volume. Coefficients with positive or negative values, indicate the influence of the trait on the component (ROSO; FRIES, 1995). Thus, the body weight and the thoracic perimeter presented higher values for the evaluated ages and were more important in determining the coefficients of the first principal component (Table 3).

The second principal component for traits at birth (Table 3) represented $16 \%$ of the total variance and compared body length to other measurements at this period. Thus, in that component, animals with positive deviations for body length presented negative deviations for weight, thoracic perimeter, and wither height. Longer individuals presented lower weight, lower perimeter, and lower wither height.

The third component for the traits at birth (Table 3) accumulated a small percentage of the total variance. In this case, lambs with greater body length and wither height presented lower weight and thoracic perimeter at birth, that is, longer and taller lambs were also lighter and thinner at birth.

The second principal component of the measurements, performed at 28 days of age, explained only $6 \%$ of the total variance. However, interestingly, it contrasts wither height, body length, and thoracic perimeter at 28 days of age. Thus, animals with positive deviations for wither height caused negative deviations for body length and thoracic perimeter. This component generally compares taller, shorter, and narrower lambs with smaller, longer, and wider lambs, respectively. The coefficient for body weight in this case was small. The third principal component for 28 days of age represented only $2 \%$ of the total variability. Lambs that were above average for length and thoracic perimeter were compared with those of negative deviations for weaning weight and wither height.

The second principal component differentiated the animals at weaning (70 days of age) comparing taller and heavier animals with smaller and lighter ones. The third component for measurements presented a similar result for those verified at 28 days and can be interpreted similarly. Roso and Fries (1995) found similar results for Polled Hereford cattle when comparing weight at weaning and at 550 days, and mentioned that the similarity of interpretations in the two periods indicates that the biological and environmental relationships were similar.

The lambs that presented high and positive values for thoracic perimeter at 28 days of age and 
at weaning were more compact and precocious than those who presented high and negative values for thoracic perimeter at of the same age and were more slender, but, presented the same body volume or size, since this component is orthogonal to the first one. Thus, the first component is an indicator of body size or volume and the second one of conformation, which makes possible to select bulky and young animals. Based on the presented results, the thoracic perimeter and the body weight can be considered as the main measures of growth of the animals at weaning, which means that the animals could be selected by thoracic perimeter and weight.

The second principal component for traits at birth, 28, and 70 days of age, explained $16 \%, 6 \%$, and $14 \%$, respectively, of the variation between the individuals (Table 3). Those animals can be interpreted as individuals of different conformations, which presented the same total volume or body mass, because this component is orthogonal to the first one.

According to Souza et al. (2010), the use of principal components in the selection of beef cattle allows the production of precise indexes for the selection of weighted economic variables. Koritiaki et al. (2013) reported that weight, wither height, and the thoracic perimeter are important biometric measures related to the growth traits of lambs and can be used in the selection of these animals from birth to weaning. Fajemilehin and Salako (2008) found high and positive correlations between body weight and biometric measurements (thoracic perimeter, wither height, and body length) in sheep up to one year of age.

The principal component analysis between weight and biometric measurements contributes to a more complete observation of the variations in the shape and conformation of the animals, supporting the understanding of their structure (BROWN et al. 1973). Thus making possible the early identification of more volumous, compact and precocious animals with a good slaughter conformation.

\section{Conclusion}

The coefficients of the first principal component adjusted for weight and average daily gain and measured from birth to 70 days of age, showed very close values, indicating that the selection for improved traits may be made at any stage during this period.

The major cause of variation among animals for weights and biometric measures is related to differences in body sizes and volumes, followed by differences in animal conformation.

The thoracic perimeter and weight at different ages were the most important characteristics as indicators of animal conformation.

\section{References}

BAKER, J. F.; STEWART, T. S.; LONG, C. R.; CARTWRIGTH, T. C. Multiple regression and principal components analysis of puberty and growth in cattle. Journal of Animal Science, Champaign,v. 66, n. 9, p. 2147-2158, 1988. DOI:10.2527/jas1988.6692147x

BOUJANE, I.; DIALLO, I. T. Estimates of genetic parameters and genetic trends for pre-weaning growth traits in Sardi sheep. Small Ruminant Research, Amsterdam, v. 146, n. 2017, p. 61-68, 2017. DOI: 10.1016/j.smallrumres. 2016.12.002

BROWN, C. J.; BROWN, I. E.; BUTTS, W. T. Evaluating relationships among immature measures of size, shape and performance of beef bulls. Journal of Animal Science, Champaign, v. 36, n. 6, p. 1021-1031, 1973. DOI: $10.2527 /$ jas $1973.3661010 x$

FAJEMILEHIN, O. K. S.; SALAKO, A. E. Body measurement characteristics of the West African Dwarf (WAD) goat in deciduous forest zone of Southwestern Nigeria. African Journal of Biotechnology, Nairobi, v. 7, n. 14, p. 2521-2526, 2008.

GUEDES, D. G. P.; RIBEIRO, M. N.; CARVALHO, F. F. R. Multivariate techniques in the analysis of carcass traits of Morada Nova breed sheep. Ciencia Rural, Santa Maria, v. 48, n. 9, p. 1-7, 2018. DOI: 10.1590/0103$8478 \mathrm{cr} 20170746$

KORITIAKI, N. A.; RIBEIRO, E. L. A.; MIZUBUTI, I. Y.; SILVA, L. D. F.; BARBOSA, M. A. A. F.; BUMBIERIS JUNIOR, V. H.; CASTRO, F. A. B.; CONSTANTINO, C. Influence of environmental 
factors on ponderal performance and morphometric characteristics of lambs of different genetic groups from birth to weaning. Revista Brasileira de Zootecnia, Viçosa, MG, v. 42, n. 7, p. 1806-9290, 2013. DOI: 10.1590/S1516-35982013000700001

LANDIM, A. V.; MARIANTE, A. S.; McMANUS, C.; GUGEL, R.; PAIVA, S. R. Características quantitativas da carcaça, medidas morfométricas e suas correlações em diferentes genótipos de ovinos. Ciência Animal Brasileira, Goiânia, v. 8, n. 4, p. 665-676, out./dez. 2007.

MORRISON, D. F. Multivariate statistical methods. $2^{\text {th }}$ ed. New York: McGraw-Hill, 1976. 415 p.

MUNIZ, C. A. S. D.; QUEIROZ, S. A.; MASCIOLI, A. S.; ZADRA, L. E. F. Análise de componentes principais para características de crescimento em bovinos de corte. Semina: Ciências Agrárias, Londrina, v. 35, n. 3, p. 15691576, 2014. DOI: 10.5433/1679-0359.2014v35n3p1569

PIRES, M. P.; FARAH, M. M.; CARREÑO, L. O. D.; UTSUNOMIYAL, A. T. H.; ONOL, R. K.; BERTIPAGLIAL, T. S.; FONSECA, R. Estimativas de parâmetros genéticos para características de crescimento em ovinos da raça Suffolk no Brasil. Arquivo Brasileiro de Medicina Veterinária e Zootecnia, Belo Horizonte, v. 67 , n. 4, p. 1119-1124, 2015. DOI: 10.1590/1678-41626949
ROSO, V. M.; FRIES, L. A. Componentes principais em bovinos da raça Polled Hereford a desmama e sobreano. Revista Brasileira de Zootecnia, Viçosa, MG, v. 24, n. 5, p. 728-735, 1995.

SILVA, S. M.; SHIOTSUKI, L.; LÔBO, R. N. B.; FACÓ, O. Análise de componentes principais para avaliação de um método de classificação utilizado nos testes de desempenho em ovinos da raça Morada Nova. Semina: Ciências Agrárias, Londrina, v. 36, n. 6, p. 3909-3922, nov./dez. 2015. DOI: 10.5433/16790359.2015v36n6p3909

SOUZA, J. C.; PEROTTO, D.; ABRAHA, J. J.; FREITAS, J. A.; FERRAZ FILHO, P. B.; WEABER, R. L.; LAMBERSON, W. R. Estimativa das distâncias genéticas e componentes principais em bovinos de corte no Brasil. Archivos de Zootecnia, Córdoba, v. 59, n. 228, p. 479-485, 2010.

STATISTICAL ANALYSIS SYSTEM INSTITUTE - SAS Institute Inc. SAS ${ }^{\circledR}$ STUDIO. User`s Guides, version 3.5. Cary: SAS Institute Inc., 2016. 198 p. 
